\title{
Coinfections with hepatitis $B$ and $C$ virus and syphilis among HIV-infected clients in Southern Ethiopia: a cross-sectional study
}

This article was published in the following Dove Press journal: HIVIAIDS - Research and Palliative Care

\author{
Techalew Shimelis' \\ Yayheyirad Tassachew' \\ Agete Tadewos' \\ Mesfin Worku Hordofa' \\ Anteneh Amsalu ${ }^{2}$ \\ Birkneh Tilahun Tadesse ${ }^{3}$ \\ Endale Tadesse' \\ 'Department of Medical Laboratory \\ Science, College of Medicine and \\ Health Sciences Hawassa University, \\ Hawassa, ${ }^{2}$ Department of Medical \\ Microbiology, School of Biomedical \\ and Laboratory Sciences, University \\ of Gondar, Gondar, ${ }^{3}$ Department of \\ Pediatrics, School of Medicine, College \\ of Medicine and Health Sciences, \\ Hawassa University, Hawassa, Ethiopia
}

Correspondence: Anteneh Amsalu Department of Medical Microbiology, University of Gondar, P.O. Box 196, Gondar, Ethiopia

Tel +25I 910047320

Email ant.amsalu@gmail.com
Introduction: Hepatitis B virus (HBV) and hepatitis C virus (HCV) are hepatotropic viruses of public health significance worldwide. Despite their severe clinical impact in HIV-infected patients, there is inadequate information regarding the epidemiology of hepatitis/HIV coinfections in Ethiopia. Thus, this study aimed to determine the prevalence of HBV and HCV infections among HIV-infected patients at a tertiary hospital in Southern Ethiopia.

Methods: Stored sera, which were originally collected for the investigation of syphilis among HIV-infected clients, were analyzed in this study. Samples were tested for hepatitis B surface antigen (HBsAg) and antibody to hepatitis B core antigen using rapid diagnostic tests. Those samples that tested positive for HBsAg were further analyzed for hepatitis B e antigen. All sera were tested for antibody to $\mathrm{HCV}$ infection using rapid diagnostic test.

Results: HBsAg was positive for $6.3 \%$ of the participants; of whom, $10 \%$ were positive for hepatitis B e antigen. The exposure rates to HBV (antibody to hepatitis B core antigen) and HCV (anti-HCV) infections were 22.4 and $3.1 \%$, respectively. The rates of coinfections with HBVsyphilis, HCV-syphilis, and HBV-HCV were found to be $3.1,0.6$, and $1.3 \%$, respectively. HBV exposure rate was significantly higher among participants in the age range 40-49 years (adjusted odds ratio [AOR], 1.98; 95\% CI, 1.01-3.88) and those who had a CD4+ T cell count $<200$ cells/ $\mu \mathrm{L}$ (AOR, 2.40; 95\% CI, 1.13-5.10) and 200-349 cells/ $\mu \mathrm{L}$ (AOR, 2.36; 95\% CI, 1.28-4.35).

Conclusion: The rates of HBV and HCV infections were found to be similar to other subpopulations in Ethiopia. Age and CD4+ T cell level influenced the rate of HBV exposure. As human immunodeficiency virus-hepatitis coinfections are clinically consequential in people living with human immunodeficiency virus/acquired immunodeficiency syndrome, the need to screen this population for HBV and HCV infections is critically important.

Keywords: HBV, HCV, HIV, syphilis, coinfection, prevalence

\section{Background}

Hepatitis B virus (HBV) and hepatitis $\mathrm{C}$ virus (HCV) infections cause serious public health problems worldwide. An estimated 2 billion and 180 million people globally have been infected with $\mathrm{HBV}$ and $\mathrm{HCV}$, respectively, of whom, $>378$ million HBV cases and up to 170 million $\mathrm{HCV}$ cases are chronic carriers at risk of developing liver cirrhosis and/or liver cancer. About 620,000 people with HBV infection and $>350,000$ people with $\mathrm{HCV}$ die annually from the respective virus-related liver disease. ${ }^{1,2}$

The global prevalence of chronic HBV infection varies widely, from high $(\geq 8 \%$, e.g., Africa, Asia, and the western Pacific) to intermediate $(2 \%-7 \%$, e.g., Southern and Eastern Europe) and low $(<2 \%$, e.g., Western Europe, North America and Aus- 
tralia). ${ }^{3}$ Most HBV infections in sub-Saharan Africa occur during perinatal period or early in childhood, resulting in higher risk of chronicity (up to $90 \%$ ) and death $(25 \%) .{ }^{4} \mathrm{HCV}$ prevalence is high $(\geq 3 \%)$ in many countries in Eastern Europe and Latin America, and, the Middle East, South Asia, and certain countries in Africa (particularly Egypt); moderate prevalence $(2 \%-2.9 \%)$ in most African countries; and low prevalence $(1.0 \%)$ in Western Europe, USA and Australia. ${ }^{2}$ HCV infection in $50 \%-80 \%$ of adults takes a chronic course; $20 \%-50 \%$ of whom develop cirrhosis or cancer of the liver. ${ }^{5}$

The main ways of getting infected with HBV are perinatal (from mother to baby at birth), child-to-child transmission, sexual contact, transfusion of infected blood or blood products and re-use of HBV-contaminated needles, syringes, lancets and instruments. ${ }^{6}$ Transmission of $\mathrm{HCV}$ is primarily by blood-to-blood contact while a large or repeated exposures to infectious blood such as receiving unscreened blood and unsafe needle injection occurs. High-risk sexual exposures and perinatal transmissions are also important. ${ }^{7}$

The shared transmission routes among blood-borne infections such as human immunodeficiency virus (HIV), HBV, $\mathrm{HCV}$, and syphilis increase their co-existence rate in a single host. $^{5-8}$ The estimated $2-4$ million people with HIV-HBV and 4-5 million with HIV-HCV emphasize the significance of coinfections with these viruses of major health impacts. ${ }^{6}$ The adverse interactions of co-existing viruses are suggested to worsen the clinical outcome and impact the epidemiology of either infection. For instance, patients with HIV-HBV coinfections are more likely to become HBV chronic carriers, have active $\mathrm{HBV}$ replication, remain hepatitis $\mathrm{B}$ e antigen ( $\mathrm{HBeAg}$ ) carriers for a longer period, and have $\mathrm{HBV}$ reactivation. ${ }^{5,8,9}$ Furthermore, HIV exacerbates liver disease in HBV and/or HCV coinfected patients, even as they are on highly active anti-retroviral therapy. ${ }^{9,10}$ These complications are now the leading causes of death in HIV-infected patients. ${ }^{7}$

Overall, viral hepatitis either alone or as coinfection with HIV has been a major public health problem. Available evidence indicates that $\mathrm{HBV}^{11,12}$ and $\mathrm{HCV}^{13,14}$ infections are endemic in Ethiopia where HIV and syphilis are also prevalent. No antiviral agents for HBV are available in the country, but a private institution in Addis Ababa has started delivering antiviral treatment service for $\mathrm{HCV}$ infection. Moreover, HBV vaccine has been given for infants as part of the National Expanded Program on Immunization since 2007, whereas the vaccine for adults is only available in the private institutions and is expensive.

The shared transmission routes, mainly heterosexual exposure, may be attributed to the observed strong association between HIV and syphilis in Ethiopia. ${ }^{15}$ In the same context, where data on mode of transmission and age of participants at $\mathrm{HBV}$ or HCV infection among HIV-positive people is absent, assessing the coinfection rate among these viruses may indirectly indicate the routes of transmission. However, most coinfection studies in Ethiopia investigated a serological marker of active HBV infection (hepatitis B surface antigen [HBsAg]) and overlooked the importance of analyzing a marker of exposure (antibody to hepatitis B core antigen [anti-HBc]) in assessing the status of association. This limits the opportunity to better describe the degree of association among HBV, HCV, syphilis, and HIV infections. Therefore, the current study was designed to determine the coinfection rate with $\mathrm{HBV}, \mathrm{HCV}$ and syphilis and their predictors among HIV-infected clients attending the antiretroviral therapy (ART) clinic of a tertiary hospital in Southern Ethiopia and these findings would affect the local guidelines.

\section{Methods}

\section{Study setting and samples}

This cross-sectional study was conducted at Hawassa University Hospital, Southern Ethiopia from October to November 2015. The hospital routinely provides HIV testing and counseling service for clients at voluntary counseling and testing center. Those clients who are found to be HIV infected have regular follow-up at the ART clinic of the hospital. Sera collected originally for the purpose of investigating the epidemiology of syphilis in a consecutive series of HIVinfected patients attending the ART clinic of the hospital from January to May 2014 were analyzed in the study after a year of storage at $-80^{\circ} \mathrm{C}$. HIV-infected children under 15 years of age were excluded originally because they were few in number and might not have similar sexual behavior with adults. Moreover, clients who got treated for syphilis or with a CD4+ T cell count $\leq 50$ cells $/ \mu \mathrm{L}$ were excluded since serological tests might be unreliable in those cases. In total, 21 clients who met the exclusion criteria were not considered in the study. ${ }^{16}$ The current study analyzed 477 sera that were selected with a lottery method from a total of 993 stored sera after the sample identification numbers were listed in ascending order.

\section{Data collection}

Data on sociodemography (age, sex, occupation, educational level, residence) and risk factors (marital status, history of medical and traditional practices, history of sexually transmitted infections [STIs], sexual practices) 
were originally collected using questionnaire. Clinical data related to patients' ART status and CD4+ T cell count were also collected.

\section{Serological testing}

In the current study, sera were tested for various markers of HBV and HCV infections. The presence of HBsAg and anti-HBc were determined using commercially available rapid diagnostic tests (RDTs) (Tulip Diagnostics, Verna, Goa, India). Those samples, which were found to be positive for $\mathrm{HBsAg}$, were further analyzed for $\mathrm{HBeAg}$. Detection of antibody to $\mathrm{HCV}$ infection was performed using RDT (CTK Biotech, Inc, San Diego, CA, USA). All tests were carried out according to the instructions of the manufacturers. Sera were previously characterized for syphilis with a rapid plasma reagin (RPR), and positive results were further confirmed by modified Treponema pallidum haemagglutination assay (TPHA).

\section{Definitions}

Current HBV infection: HIV-infected individuals whose serum sample tested positive for HBsAg.

Exposure to HBV infection: Those whose serum samples tested positive for anti-HBc, and indicated a current or resolved infection.

Active HBV replication: Those whose serum sample tested positive for $\mathrm{HBeAg}$ and indicated they are highly infectious.

Exposure to HCV infection: Those whose serum sample were serologically positive for anti-HCV and indicated current or resolved infection.

Current syphilis: Those whose serum samples were found to be positive with RPR and TPHA.

\section{Data analysis}

Data entry and analysis was performed using SPSS Version-16. Results were summarized using frequencies and proportions, and presented in tables. Chi-square test was performed to assess difference between the rate of hepatitis and/or syphilis with ART status. The association between HBV exposure and sociodemographic and other risk factors was assessed using crude odds ratio from a binary logistic regression analysis. Adjusted odds ratio (AOR) was also computed using multivariable logistic regression analysis, taking all factors yielding a $p$ value $\leq 0.05$ in bivariate analysis. A $p$ value $\leq 0.05$ was considered to be statistically significant association.

\section{Results}

A total of 477 sera, collected from HIV-infected clients and characterized with respect to syphilis sero-status, were analyzed for serological markers of HBV and HCV infections. Most study participants were females (61\%) and urban residents $(94.3 \%)$. The mean age of the clients was 33.4 years (SD 9.1, range 15-75 years), and those in the age range 30-39 years accounted for $42.9 \%$. Participants who were never married and completed a secondary level education were 44.4 and $39.8 \%$, respectively. The median CD4+ $\mathrm{T}$ cell count was 432 cells $/ \mu \mathrm{L}$ (range $51-1614$ cells $/ \mu \mathrm{L}$ ), and $10.5 \%$ of the participants had cell count $<200$ cells $/ \mu \mathrm{L}$. Majority of the respondents $(84.7 \%)$ were on ART, and had received the treatment for median duration of 47 months (range 1-113 months) (Table 1).

As analyzed originally, $11.9 \%$ of the samples considered in the current study were sero-positive for syphilis. The prevalence of HBsAg, anti-HBc, and anti-HCV markers among the study participants was $6.3,22.4$, and $3.2 \%$, respectively. On further analysis of $\mathrm{HBsAg}$ positive samples, $10 \%$ (3/30) were found to be positive for $\mathrm{HBeAg}$. All samples with $\mathrm{HBsAg}$ were also positive for anti-HBc marker. Overall, 33.5\% of the investigated HIV-infected samples, had at least 1 marker of the other infections, syphilis, HBV or HCV. Further, $(5.03 \%)$ of the samples were positive for markers indicating 2 of these agents. However, none of the samples were positive for markers revealing triple infections with the agents Coinfections with anti-HBc/syphilis, anti-HCV/syphilis, and anti-HBc/anti-HCV were detected in 3.1, 0.6 , and $1.3 \%$ of the participants, respectively. ART status did not influence the sero-positivity rate of any of the markers $(p>0.05)$ (Table 2$)$.

The serological evidence of exposure to HBV infection (anti-HBV) was observed in $29.6 \%$ of rural residents, $23.6 \%$ of females, $28.6 \%$ of those aged $40-49$ years, $26.7 \%$ of daily laborers, and $28.9 \%$ of widowers. A higher rate of anti-HBc antibody was also observed among participants with a CD4+ T cell count $<200$ cells $/ \mu \mathrm{L}(32 \%)$, followed by those in the range 200-349 cells/ $\mu \mathrm{L}(31 \%)$. In bivariate analysis, HBV exposure was shown to have a significant association with age or level of CD4+ T cell count. However, the rate of HBV exposure was not significantly associated with factors such as residence, sex, occupation, educational level, marital status, and ART status (Table 1). The rate of other markers, including HBsAg and anti-HCV, was not found to be influenced by sociodemographic or other factors. The analysis regarding the distribution of syphilis in relation to the assessed factors was reported elsewhere. ${ }^{16}$ 
Table I HBV exposure rates in relation to sociodemography, CD4+ count, and ART status in HIV-infected individuals in Southern Ethiopia, 2015

\begin{tabular}{|c|c|c|c|c|}
\hline Characteristics & $\begin{array}{l}\text { Number (\%) } \\
\text { tested }\end{array}$ & $\begin{array}{l}\text { Number (\%) positive } \\
\text { for anti-HBc }\end{array}$ & COR $(95 \% \mathrm{Cl})$ & $p$-value \\
\hline \multicolumn{5}{|l|}{ Residence } \\
\hline Rural & $27(5.7)$ & $8(29.6)$ & I & \\
\hline Urban & $450(94.3)$ & $99(22)$ & $\mathrm{I} .49(0.63-3.5 \mathrm{I})$ & 0.359 \\
\hline \multicolumn{5}{|l|}{ Sex } \\
\hline Female & $291(6 I)$ & $63(21.6)$ & 1 & \\
\hline Male & $186(39)$ & $44(23.7)$ & $1.12(0.72-1.74)$ & 0.608 \\
\hline \multicolumn{5}{|l|}{ Age (years) } \\
\hline$<29$ & $170(35.6)$ & $28(16.5)$ & 1 & \\
\hline $30-39$ & $204(42.9)$ & $51(25)$ & $1.72(1.03-2.88)$ & $0.038^{a}$ \\
\hline $40-49$ & $70(14.7)$ & $20(28.6)$ & $2.03(1.05-3.91)$ & $0.035^{\mathrm{a}}$ \\
\hline$\geq 50$ & $32(6.7)$ & $7(21.9)$ & $1.42(0.56-3.60)$ & 0.460 \\
\hline \multicolumn{5}{|l|}{ Occupation } \\
\hline Employee & 95 (19.9) & $22(23.2)$ & $1.42(0.72-2.79)$ & 0.314 \\
\hline Daily laborer & $60(12.6)$ & $16(26.7)$ & I.7I $(0.8 I-3.6 I)$ & 0.161 \\
\hline Student/jobless & $85(17.8)$ & $19(22.4)$ & $1.35(0.67-2.73)$ & 0.399 \\
\hline Merchant & 89 (18.7) & $22(24.7)$ & $1.54(0.78-3.05)$ & 0.212 \\
\hline Farmer/housemaid & $34(7.1)$ & $8(23.5)$ & $1.45(0.57-3.66)$ & 0.436 \\
\hline Self-employed & $114(23.9)$ & $20(17.5)$ & 1 & \\
\hline \multicolumn{5}{|l|}{ Educational status } \\
\hline No formal & $64(13.4)$ & $15(23.4)$ & 1 & \\
\hline Primary school & $148(31.0)$ & $32(21.6)$ & $0.90(0.0 .45-1.8 I)$ & 0.770 \\
\hline Secondary school & $190(39.8)$ & $4 \mid(2 \mid .6)$ & $0.89(0.46-1.76)$ & 0.756 \\
\hline Certificate and above & $75(15.7)$ & $19(25.3)$ & $I .1 I(0.5 I-2.4 I)$ & 0.796 \\
\hline \multicolumn{5}{|l|}{ Marital status } \\
\hline Married (never D/W) & $212(44.4)$ & $42(19.8)$ & 1 & \\
\hline Married (previous D/W) & $110(23.1)$ & $28(25.5)$ & $1.38(0.80-2.39)$ & 0.245 \\
\hline Never married & $73(15.3)$ & $16(21.9)$ & $1.14(0.59-2.18)$ & 0.700 \\
\hline$D$ & $44(9.2)$ & $10(22.7)$ & $1.19(0.55-2.60)$ & 0.700 \\
\hline W & $38(8.0)$ & II (28.9) & $1.65(0.76-3.59)$ & 0.662 \\
\hline \multicolumn{5}{|l|}{ CD4+ T cells/pL } \\
\hline$<200$ & $50(10.5)$ & $16(32.0)$ & $2.48(1.17-5.25)$ & $0.017^{\mathrm{a}}$ \\
\hline $200-349$ & $113(23.7)$ & $35(31.0)$ & $2.37(1.29-4.34)$ & $0.005^{\mathrm{a}}$ \\
\hline $350-499$ & $138(28.9)$ & $22(15.9)$ & 1 & \\
\hline$\geq 500$ & $176(36.9)$ & $34(19.3)$ & $1.26(0.70-2.28)$ & 0.439 \\
\hline \multicolumn{5}{|l|}{ ART } \\
\hline Yes & $404(84.7)$ & $91(22.5)$ & $1.04(0.57-1.89)$ & 0.909 \\
\hline No & $73(15.3)$ & $16(21.9)$ & 1 & \\
\hline
\end{tabular}

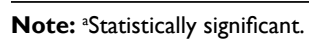

Abbreviations: HBV, hepatitis B virus; anti-HBc, antibody to hepatitis B core antigen; ART, antiretroviral therapy; CD, cluster of differentiation; COR, crude odds ratio; $D$, divorced; W, widowed.

On further analysis taking age and CD4+ T cell count into a multivariable logistic regression model, participants in the age range of 30-39 years (AOR, 1.64; 95\% CI, 0.97-2.77; $p=0.067$ ) and 40-49 years (AOR, 1.98; 95\% CI, 1.01-3.88; $p=0.046$ ) had higher odds of HBV exposure compared with age $<20$ years. Moreover, HBV exposure rate decreased with increasing CD4 $\mathrm{T}$ cell count where participants with counts $<200$ cells $/ \mu \mathrm{L}$ (AOR, 2.40 ; 95\% CI, 1.13-5.10; $p=0.023)$ and with $200-349$ cells/ $\mu \mathrm{L}$ (AOR, 2.36; 95\% CI, 1.28-4.35; $p=0.006$ ) had more HBV exposure rate compared with those in the range $350-499$ cells $/ \mu \mathrm{L}$.
Out of the study participants, $4 \%$ had a history of blood transfusion, $7.8 \%$ had scarring, $14.5 \%$ drank alcohol during sexual intercourse, and $48.2 \%$ had not used condom. Further, the age at sexual debut for $46.5 \%$ of the participants was $<20$ years; $47.8 \%$ had $2-5$ life-time sexual partners, and $23.3 \%$ reported a history of STIs. The rate of exposure to HBV infection was higher in those with a history of blood transfusion (26.3\%), had scarring and tattooing (32.4\%), sometimes used alcohol during sex (26.1\%), and circumcised (33.3\%). However, none of the association between the assessed risk factors and HBV exposure status was found to be statistically significant (Table 3). 
Table 2 HBV, HCV, syphilis serological markers in HIV-infected individuals with and without ART in Southern Ethiopia, 2015

\begin{tabular}{|c|c|c|c|c|c|c|c|}
\hline \multirow[t]{3}{*}{ Serological marker } & \multirow{3}{*}{$\begin{array}{l}\text { Total } \\
\text { tested }\end{array}$} & \multirow{3}{*}{$\begin{array}{l}\text { Positive, } \\
\text { n (\%) }\end{array}$} & \multicolumn{4}{|c|}{ HIV-infected participants } & \multirow[t]{3}{*}{$p$-value } \\
\hline & & & \multicolumn{2}{|c|}{ On ART } & \multicolumn{2}{|c|}{ ART-naïve } & \\
\hline & & & Tested & Positive, n (\%) & Tested & Positive, n (\%) & \\
\hline $\mathrm{HBsAg}$ & 477 & $30(6.3)$ & 404 & $29(7.2)$ & 73 & I (I.4) & 0.060 \\
\hline $\mathrm{HBeAg}$ & 30 & $3(10.0)$ & 29 & $3(10.3)$ & 1 & 0 & - \\
\hline Anti-HBc & 477 & $107(22.4)$ & 404 & $91(22.5)$ & 73 & $16(21.9)$ & 0.909 \\
\hline Syphilis & 477 & $57(11.9)$ & 404 & $46(11.4)$ & 73 & II (I5.I) & 0.372 \\
\hline Anti-HCV & 477 & $15(3.1)$ & 404 & $13(3.2)$ & 73 & $2(2.7)$ & 0.648 \\
\hline Anti-HBc-Syphilis & 477 & $15(3.1)$ & 404 & II (2.7) & 73 & $4(5.5)$ & 0.172 \\
\hline Anti-HCV-Syphilis & 477 & $3(0.6)$ & 404 & $2(0.5)$ & 73 & I ( 1.4$)$ & - \\
\hline HBV-HCV & 477 & $6(1.3)$ & 404 & $5(1.2)$ & 73 & I (I.4) & 0.904 \\
\hline
\end{tabular}

Abbreviations: anti- $\mathrm{HBc}$, antibody to hepatitis $\mathrm{B}$ core antigen; anti-HCV, antibody to hepatitis $\mathrm{C}$ virus; $\mathrm{ART}$, antiretroviral therapy; $\mathrm{HBV}$, hepatitis $\mathrm{B}$ virus; $\mathrm{HBeAg}$, hepatitis $B$ e antigen; $\mathrm{HBs} A g$, hepatitis $B$ surface antigen; $\mathrm{HCV}$, hepatitis $\mathrm{C}$ virus; $\mathrm{HIV}$, human immunodeficiency virus.

Table 3 HBV exposure rate in relation to risk factors in HIV-infected individuals in Southern Ethiopia, 2015

\begin{tabular}{|c|c|c|c|c|}
\hline Characteristics & $\begin{array}{l}\text { Tested, } \\
\text { n (\%) }\end{array}$ & $\begin{array}{l}\text { Positive for } \\
\text { anti-HBc, n (\%) }\end{array}$ & COR $(95 \% \mathrm{Cl})$ & $p$-value \\
\hline \multicolumn{5}{|c|}{ History of blood transfusion } \\
\hline No & $458(96.0)$ & $102(22.3)$ & I & \\
\hline Yes & $19(4.0)$ & $5(26.3)$ & $1.25(0.44-3.54)$ & 0.679 \\
\hline \multicolumn{5}{|l|}{ Unsafe injection } \\
\hline No & $432(90.6)$ & $99(22.9)$ & $1.38(0.62-3.05)$ & 0.433 \\
\hline Yes & $45(9.4)$ & $8(17.8)$ & 1 & \\
\hline \multicolumn{5}{|l|}{ Circumcised } \\
\hline No & $9(1.9)$ & $3(33.3)$ & $1.75(0.43-7.12)$ & 0.434 \\
\hline Yes & $968(98.1)$ & $104(22.2)$ & 1 & \\
\hline \multicolumn{5}{|c|}{ Traditional procedures } \\
\hline No & $399(83.6)$ & $83(20.8)$ & 1 & \\
\hline Scarring/blood & $44(9.2)$ & $13(29.5)$ & $1.60(0.80-3.19)$ & 0.185 \\
\hline \multicolumn{5}{|l|}{ letting } \\
\hline Tattooing & $34(7.1)$ & II (32.4) & $1.82(0.85-3.89)$ & 0.121 \\
\hline \multicolumn{5}{|c|}{ Age at sexual debut (years) } \\
\hline$<20$ & $222(46.5)$ & $44(19.8)$ & 1 & \\
\hline $20-29$ & $24 I(50.5)$ & $60(24.9)$ & $1.34(0.86-2.08)$ & 0.192 \\
\hline$\geq 30$ & $14(2.9)$ & $3(2 \mid .4)$ & $1.10(0.29-4.12)$ & 0.884 \\
\hline \multicolumn{5}{|l|}{ Sex partners } \\
\hline I & $231(48.4)$ & $57(24.7)$ & $\mathrm{I} .30(0.83-2.0 \mathrm{I})$ & 0.249 \\
\hline $2-5$ & $228(47.8)$ & $46(20.2)$ & I & \\
\hline$>5$ & $18(3.8)$ & $4(22.2)$ & $1.13(0.36-3.60)$ & 0.836 \\
\hline \multicolumn{5}{|c|}{ Alcohol during sex } \\
\hline No & $403(84.5)$ & $88(2 \mid .8)$ & 1 & \\
\hline Sometimes/often & $74(15.5)$ & $19(25.7)$ & $1.24(0.70-2.9)$ & 0.467 \\
\hline \multicolumn{5}{|l|}{ Drugs during sex } \\
\hline No & 435 (9I.2) & $97(22.3)$ & 1 & \\
\hline Sometimes/often & $42(8.8)$ & $10(23.8)$ & $1.09(0.52-2.29)$ & 0.823 \\
\hline \multicolumn{5}{|l|}{ Condom use } \\
\hline No & $230(48.2)$ & $50(21.7)$ & 1 & \\
\hline Sometimes & $106(22.2)$ & $26(24.5)$ & $1.17(0.68-2.01)$ & 0.570 \\
\hline Always & I4I (29.6) & $31(22.0)$ & $1.01(0.61-1.68)$ & 0.955 \\
\hline \multicolumn{5}{|l|}{ STIs } \\
\hline No & $366(76.7)$ & $85(23.2)$ & $1.22(0.72-2.07)$ & 0.452 \\
\hline Yes & III (23.3) & $22(19.8)$ & I & \\
\hline
\end{tabular}

Abbreviations: anti-HBc, antibody to hepatitis B core antigen; COR, crude odds ratio; HIV, human immunodeficiency virus; HBV, hepatitis B virus; STIs, sexually transmitted infections. 


\section{Discussion}

We determined the prevalence of HBV and HCV infections among people living with HIV for whom syphilis sero-status was previously characterized. The rate of $\mathrm{HBsAg}$ carriage among the study participants was $6.3 \%$. Of those with $\mathrm{HBsAg}, 10 \%$ were positive for $\mathrm{HBeAg}$ marker, indicating an active replication of HBV. The rates of exposure to infections with HBV (anti-HBc) and HCV (anti-HCV) were found to be $22.4 \%$ and $3.1 \%$, respectively. The rates of coinfections with HBV-syphilis, HCV-syphilis, and HBV-HCV were $3.1 \%$, $0.6 \%$, and $1.3 \%$, respectively.

The observed rate of active HBV infection (as marked by HBsAg) in the current study was concordant with results among HIV-infected population in various localities: central Ethiopia (Addis Ababa) (3.9\%), ${ }^{17}$ north Ethiopia (Mekelle) (5. 9\%), ${ }^{18,19}$ and northwest Ethiopia (Gondar) (5.6\%). ${ }^{19}$ The similar rate of HBsAg between HIV-infected population and the general population $(7 \%)^{11}$ or other subpopulations such as pregnant women $(3.8 \%-6 \%),{ }^{20-22}$ blood donors $(4.7 \%-10.9 \%),{ }^{17,23}$ and diabetic patients $(3.7 \%)^{24}$ in Ethiopia highlights HIV-infected people might not be different from other subpopulations with respect to HBsAg clearance rate. A lower rate of HBsAg carriage in the current study compared with the mean $15 \%$ among HIV-infected people in sub-Sahara Africa ${ }^{25}$ may be due to deference in epidemiology of HBV infection by country as also evidenced by varying prevalence of anti- $\mathrm{HBc}$ (range, 23.8\%-90.0\%). In fact, difference in HBsAg clearance rate could not be ruled out as the rates of HBsAg versus anti-HBc in different African countries look dissimilar. ${ }^{25}$ However, considering the large number of HIV-infected population in Ethiopia, the observed magnitude of HBsAg carriage is of concern and demands interventions that reduce consequences.

The rate of life-time exposure to HBV infection in the current study was lower compared with the result in our previous study in Addis Ababa $(47.5 \%)^{12}$ or the mean in sub-Saharan Africa (55.1\%). ${ }^{25}$ Furthermore, the observed rate of exposure to $\mathrm{HCV}$ infection (3.1\%) was lower than the previous result in the same hospital (10.5\%). ${ }^{26} \mathrm{How}-$ ever, reports of $6.6 \%$ in north Ethiopia (Adawa), ${ }^{27} 6 \%$ in Mekelle, ${ }^{28} 5 \%$ in Gondar ${ }^{19}$ were in agreement with the current finding. The mean anti-HCV prevalence of $6.9 \%$ in sub-Saharan Africa was also similar to our result. ${ }^{25}$ The disparity in rate of exposure to HBV or HCV infection between our current and previous investigations may be attributed to the more sensitive laboratory technique (enzyme-linked immunosorbent assay) employed in previous studies.

Because HIV, HBV, HCV and syphilis share routes of transmission, the occurrence of coinfection is not uncommon. However, the magnitude of coinfection might be influenced by factors such as the prevalence of each infection in a given community, the risk behaviors involved in the transmission, and the time/age at which a maximum exposure to each infection occurs. For example, a weaker association between HIV and HBV has been reported in developing countries where immunity resulting from a natural HBV infection early in childhood gives protection in adulthood when HIV is mainly contracted through heterosexual exposures. ${ }^{12}$ Furthermore, compared with sexual route, infections acquired through parenteral route more likely resulted in HIV-HCV coinfection. ${ }^{29}$ It may be due to difference in mode of transmission and/or time of acquisition that the association between HBV, HCV, and syphilis in the current study was non-significant. A similar report of no association between HBV and HCV infections was reported elsewhere..$^{30}$ In contrast, the shared routes of transmission, mostly homosexual contact in the case of $\mathrm{HBV}$ and intravenous drug use in $\mathrm{HCV}$, increased the strength of association. ${ }^{25}$

The increasing rate of life-time HBV exposure with age in this study was concordant with various findings ${ }^{12}$ that stated that participants in the age range 40-49 years were at higher odds of infection compared with age $<20$ years. It is perhaps because of a cumulative effect that the risk of exposure to HBV infection increases with time. Moreover, the rate of HBV infection increased with decreasing CD4+ T cell count, which patients with counts $<200$ cells $/ \mu \mathrm{L}$ and in the range 200-349 cells/ $\mu \mathrm{L}$ had significantly higher rate of HBV exposure compared with those in the range 350-499 cells $/ \mu \mathrm{L}$. This might possibly be explained by the fact that patients with a lower level of immunity are commonly at increased risk of acquiring an infection. Nevertheless, the preponderance of HBV infection among HIV-infected men compared with women reported in our previous study ${ }^{12}$ was not shown in the current investigation.

The rate of $\mathrm{HBeAg}$ carriage (10\%) among those with HBsAg marker was in agreement with our previous result in Addis Ababa (10.3\%), ${ }^{12}$ which may show a similar rate of $\mathrm{HBe} A g$ clearance. However, a contrasting finding of higher carriage rate of $\mathrm{HBeAg}(33.3 \%)$ in India among HIV-infected patients may point out the difference in $\mathrm{HBeAg}$ clearance rate by population. ${ }^{31}$ Thus, the risk of HIV-HBV co-infected popu- 
lation becoming highly infectious (as marked by HBeAg) and impacting HBV transmission may vary between populations in different geographical regions.

However, this study has limitations that sera were analyzed after a year period of storage, which might affect the detectability of serological markers for HBV and HCV infections and evaluation of occult HBV status, HBV drug-resistance mutations, HCV drug-resistance mutations, $\mathrm{HBV}$ and HCV genotypes was not performed due to lack of molecular virology laboratory facilities. Moreover, difference in diagnostic performance among commercially available hepatitis test kits and lack of information regarding details of the ART regimen might influence comparison of findings in various studies and among patients who used lamivudineor tenofovir-containing regimen compared with patients who used other regimens. The generalizability of results to all HIV-infected population may be limited by selection and information bias due to the institutional based nature of the study and the reliance on participants' report to assess exposure to risk factors,

\section{Conclusion}

As is the case in most studied subpopulations (regardless of HIV infection) in Ethiopia, an intermediate HBV infection rate (HBsAg carriage) was shown in this study. It implies that HIV-infected people may not be as such different with respect to becoming at higher risk of acquiring HBV infection. Furthermore, the observed non-significant association among HBV, HCV and syphilis may highlight the little importance of shared risk factors in the transmission of these infections. However, as the occurrence of coinfections is clinically consequential, the need to provide hepatitis screening and treatment services for HIV-infected population in Ethiopia would be critically essential.

\section{Ethics approval and consent to participate}

This study was approved by the Institutional Review Board of Hawassa University, College of Medicine and Health Sciences. Informed written consent was originally obtained from the study participants to use the leftover sera from the previous study for the current investigation. Assent was also obtained from children under the age of 18 years in addition to a written consent from their parents or guardians. Any information obtained during the study is kept with utmost confidentiality. Syphilis-infected patients were previously managed by physicians in the ART clinic. The HBV and HCV laboratory results in this study were also reported to the ART clinic for clinical management of patients on regular HIV follow-up.

\section{Availability of data and materials}

The raw data is available in SPSS file and it can be provided if requested.

\section{Acknowledgments}

The authors would like to thank Hawassa University for supporting the study with finance and laboratory facilities. We also thank the study participants who consented and allowed us to use the leftover sera for this investigation. The study was supported with a small grant obtained from Hawassa University.

\section{Author contributions}

All authors contributed toward data analysis, drafting and critically revising the paper and agree to be accountable for all aspects of the work.

\section{Disclosure}

The authors report no conflicts of interest in this work.

\section{References}

1. Franco E, Bagnato B, Marino MG, Meleleo C, Serino L, Zaratti L. Hepatitis B: epidemiology and prevention in developing countries. World J Hepatol. 2012;4(3):74-80.

2. Averhoff FM, Glass N, Holtzman D. Global burden of hepatitis C: considerations for healthcare providers in the United States. Clin Infect Dis. 2012;55(Suppl 1):S10-S15.

3. Schweitzer A, Horn J, Mikolajczyk RT, Krause G, Ott JJ. Estimations of worldwide prevalence of chronic hepatitis B virus infection: a systematic review of data published between 1965 and 2013. Lancet. 2015;386(10003):1546-1555.

4. Kwon SY, Lee CH. Epidemiology and prevention of hepatitis B virus infection. Korean J Hepatol. 2011;17(2):87-95.

5. Burnett RJ, Francois G, Kew MC, et al. Hepatitis B virus and human immunodeficiency virus co-infection in sub-Saharan Africa: a call for further investigation. Liver Int. 2005;25(2):201-213.

6. Alter MJ. Epidemiology of viral hepatitis and HIV co-infection. $J$ Hepatol. 2006;44(1 Suppl):S6-S9.

7. Brook G. Prevention of viral hepatitis in HIV co-infection. J Hepatol 2006;44(1 Suppl):S104-S107.

8. Soriano V, Barreiro P, Nunez M. Management of chronic hepatitis B and C in HIV-coinfected patients. J Antimicrob Chemother. 2006;57(5):815-818.

9. Thio CL, Seaberg EC, Skolasky R Jr, et al. HIV-1, hepatitis B virus, and risk of liver-related mortality in the Multicenter Cohort Study (MACS). Lancet. 2002;360(9349):1921-1926.

10. Sulkowski MS, Thomas DL, Mehta SH, Chaisson RE, Moore RD. Hepatotoxicity associated with nevirapine or efavirenz-containing antiretroviral therapy: role of hepatitis $\mathrm{C}$ and $\mathrm{B}$ infections. Hepatology. 2002;35(1):182-189. 
11. Abebe A, Nokes DJ, Dejene A, Enquselassie F, Messele T, Cutts FT. Seroepidemiology of hepatitis B virus in Addis Ababa, Ethiopia: transmission patterns and vaccine control. Epidemiol Infect. 2003;131(1):757-770.

12. Shimelis T, Torben W, Medhin G, et al. Hepatitis B virus infection among people attending the voluntary counseling and testing center and antiretroviral therapy clinic at St Paul's general specialized hospital Addis Ababa Ethiopia. Sex Transm Infect. 2007;84(1):37-41.

13. Tsega E, Nordenfeld E, Hansson BG. Hepatitis C Virus infection and chronic liver disease in Ethiopia where hepatitis B virus in endemic. Trans Roy Soc Trop Med Hyg. 1995;89(2):171-174.

14. Ayele W, Nokes DJ, Abebe A, et al. Higher prevalence of anti- HCV antibodies among HIV positive compared to HIV negative inhabitants of Addis Ababa, Ethiopia. J Med Virol. 2002;68(1):12-17.

15. Tulu B, Sisay Z, Alemayehu A, Shimelis T. Seroprevalence of syphilis among HIV infected individuals in Addis Ababa, Ethiopia: a hospitalbased cross-sectional study. BMJ Open. 2014;3(1):e002293.

16. Shimelis T, Lemma K, Ambachew H, Tadesse E. Syphilis among people with HIV infection: sero-prevalence and risk factors. BMC Infect Dis. 2015;15:189.

17. Mohammed Y, Bekele A. Seroprevalence of transfusion transmitted infection among blood donors at Jijiga blood bank, Eastern Ethiopia: retrospective 4 years study. BMC Res Notes. 2016;9:129.

18. Weldemhret L, Asmelash T, Belodu R, Gebreegziabiher D. Seroprevalence of HBV and associated risk factors among HIV positive individuals attending ART clinic at Mekelle hospital, Tigray, Northern Ethiopia. AIDS Res Ther. 2016;13:6.

19. Wondimeneh Y, Alem M, Asfaw F, Belyhun Y. HBV and HCV seroprevalence and their correlation with CD4 cells and liver enzymes among HIV positive individuals at University of Gondar Teaching Hospital, Northwest Ethiopia. Virol J. 2013;10:171.

20. Molla S, Munshea A, Nibret E. Seroprevalence of hepatitis B surface antigen and anti-HCV antibody and its associated risk factors among pregnant women attending maternity ward of Felege Hiwot Referral Hospital, northwest Ethiopia: a cross-sectional study. Virol J. 2015;12:204.

21. Desalegn Z, Wassie L, Beyene HB, Mihret A, Ebstie YA. Hepatitis B and human immunodeficiency virus co-infection among pregnant women in resource-limited high endemic setting, Addis Ababa, Ethiopia: implications for prevention and control measures. Eur J Med Res. 2016;21:16.
22. Zenebe Y, Mulu W, Yimer M, Abera B. Sero-prevalence and risk factors of hepatitis B virus and human immunodeficiency virus infection among pregnant women in Bahir Dar city, Northwest Ethiopia: a cross sectional study. BMC Infect Dis. 2014;14:118.

23. Tessema B, Yismaw G, Kassu A, et al. Seroprevalence of HIV, HBV, $\mathrm{HCV}$ and syphilis infections among blood donors at Gondar University Teaching Hospital, Northwest Ethiopia: declining trends over a period of five years. BMC Infect Dis. 2010;10:111.

24. Mekonnen D, Gebre-Selassie S, Fantaw S, Hunegnaw A, Mihret A. Prevalence of hepatitis B virus in patients with diabetes mellitus: a comparative cross sectional study at Woldiya General Hospital, Ethiopia. Pan Afr Med J. 2014;17:40.

25. Barth RE, Huijgen Q, Taljaard J, Hoepelman AI. Hepatitis B/C and HIV in sub-Saharan Africa: an association between highly prevalent infectious diseases. A systematic review and meta-analysis. Int $J$ Infect Dis. 2010;14(12):e1024-e1031.

26. Alemayehu A, Tassachew Y, Sisay Z, Shimelis T. Prevalence and risk factors of Hepatitis $\mathrm{C}$ among individuals presenting to HIV testing centers, Hawassa City, Southern Ethiopia. BMC Res Notes. 2011; 4:193.

27. Atsbaha AH, Asmelash Dejen T, Belodu R, Getachew K, Saravanan M, Wasihun AG. Sero-prevalence and associated risk factors for hepatitis $\mathrm{C}$ virus infection among voluntary counseling and testing and antiretroviral treatment clinic attendants in Adwa Hospital, northern Ethiopia. BMC Res Notes. 2016;9:121.

28. Hadush H, Gebre-Selassie S, Mihret A. Hepatitis C virus and human immunodeficiency virus coinfection among attendants of voluntary counseling and testing centre and HIV follow up clinics in Mekelle Hospital. Pan Afr Med J. 2013;14:107.

29. Thimme R, Spangenberg H, Blum H. Hepatitis B or hepatitis $\mathrm{C}$ and human immunodeficiency virus infection. $J$ Hepatol. 2005;42(1):S37-S44.

30. Yami A, Alemseged F, Hassen A. Hepatitis B and C viruses infections and their association with human immunodeficiency virus: a crosssectional study among blood donors in Ethiopia. Ethiop J Health Sci. 2011;21(1):67-75.

31. Chandra N, Joshi N, Raju YS, Kumar A, Teja VD. Hepatitis B and/or C co-infection in HIV infected patients: a study in a tertiary care centre from south India. Indian J Med Res. 2013;138(6):950-954.
HIV/AIDS - Research and Palliative Care

\section{Publish your work in this journal}

HIV/AIDS - Research and Palliative Care is an international, peerreviewed open access journal focusing on advances in research in HIV, its clinical progression and management options including antiviral treatment, palliative care and public healthcare policies to control viral spread. The journal is included in PubMed. The manuscript man-

\section{Dovepress}

agement system is completely online and includes a very quick and fair peer-review system, which is all easy to use. Visit http://www.dovepress. com/testimonials.php to read real quotes from published authors. 